\title{
RIBOTO PAKALTINAMUMO KRITERIJŲ TAIKYMO ANALIZE் ASMENIMS, TURINTIEMS ŠIZOFRENIJOS SPEKTRO SUTRIKIMUS
}

\author{
Konstantinas Daškevičius ${ }^{1}$, Jelena Daškevičienè ${ }^{2}$ \\ ${ }^{I}$ Nepriklausoma teismo psichiatrijos tarnyba, Vilniaus universiteto Medicinos fakulteto Psichiatrijos \\ klinika, ${ }^{2}$ Nepriklausoma teismo psichiatrijos tarnyba, Lietuvos sveikatos mokslu universiteto \\ Medicinos akademijos Psichiatrijos klinika
}

Raktažodžiai: teismo psichiatrijos ekspertizè baudžiamosiose bylose, ribotas pakaltinamumas.

\begin{abstract}
Santrauka
Tobulinant šiuolaikinę teisę, didinant jos humanistinį potencialą, įveikiant tradicinị formalistinį-biurokratinị teisès pobūdị, jos abejingumą, mažinant psichotraumuojanti poveikị asmenims, turintiems psichikos sutrikimus, 2000 metais buvo įteisinta riboto pakaltinamumo norma. Tačiau Lietuvos teismo psichiatrinejje ekspertinèje praktikoje ji mažai realizuojama, o asmenims, turintiems šizofrenijos spektro sutrikimus, taikoma itin retai, tik 10 atvejų iš 541 per 3 metus. Mūsų tyrimo duomenimis, iš $223(100 \%)$ šizofrenijos spektro sutrikimus turinčiu pakaltinamų asmenų, net $84 \%$ atitiko riboto pakaltinamumo kriterijus. Tačiau, atliekant teismo psichiatrijos ekspertizę asmenims, turintiems šizofrenijos spektro sutrikimus, nesiremiama daugiamečiu tiriamojo psichinès būklès sisteminiu vertinimu, o būtent klinikiniu biologiniu, asmenybès psichologiniu ir medicininiu socialiniu, kai svarbią vietą užima retrospektyvinis psichikos sutrikimų gylio nustatymas nusikalstamos veikos momentu. Tyrimo duomenimis, turintiems šizofrenijos spektro sutrikimus asmenims, esant nepsichozinėms būklėms, juridiniu aspektu ypatingą reikšmę turi psichopatologija, kuri pasireiškia integracineje visumoje, ir gali ją sustiprinti. O tai reiškia, kad atskirų psichopatologinių fenomenų integracija gali riboti asmens elgesio laisvę konkrečioje situacijoje. Vadinasi, ypatingą vaidmeni ekspertizei turi būtent neryškios patologijos elementų suderinimo analizè.
\end{abstract}

\section{Ivadas}

Pakaltinamumo sąvoka - viena svarbiausių šiuolaikinèje teisėsaugos sistemoje: pirmiausia, kaip asmens pakalti- namumo rodiklis, tai yra vienas iš kriterijų, nustatant kaltès ribas, kita vertus - kaip vienintelè baudžiamojoje teisèje nusakanti nusikaltèlio asmenybès ,valios laisvę", t.y. kaip baudžiamosios atsakomybès įrodymas [2, 3]. Lietuvos baudžiamojoje teisėje kaltė traktuojama kaip asmens psichikos santykis, sąmonès ir valios ryšys su daroma pavojinga veika ir pasekmèmis. Kaltès ir atsakomybès principo esmé - tai žmogaus sugebejjimas laisvai ir teisingai nuspręsti, kas yra teise ir kas yra neteisètumas [1]. Tik tuo atveju, jei egzistuoja ši sprendimo laisvè, kaltinimo pareiškimas kaltininkui turi prasmę, tačiau, jeigu visuomenė aprobuoja bausmių už tam tikrų normų pažeidimą sistemą, tai bausmès vykdymui piliečio psichikos sutrikimas yra antraeilè ir neesminè aplinkybè. "Blogis" ir "draudžiamas poelgis" yra sutartinès ir konjunktūrinès socialinès-moralinès kategorijos ir jų nustatymas bei baudžiamujų pasekmių kriterijai nepriklauso medicinos sferai. Taip suprasto blogio negalima sutapatinti su žmogaus biologija ir psichikos sutrikimais. Kitaip tariant, nepakaltinamumas nustojo būti vienareikšmiškai „geras darbas” asmenu su psichikos negalia patirčiai [7]. Kyla dilema, ar psichiatrija apskritai turi moralinę teisę keisti psichologinę žmogaus patirtị ir jo asmenybès vystymąsi su tikslu koreguoti (reikiamai formuoti) socialinį elgesị. Teismo psichiatrams tada tektų kurti nusikalstamo-socialinio deramumo arba ne deramumo standartus, taip pat vertinti, ar žmogaus elgesys prasilenkia su tais standartais, o kartu koreguoti nederamus konkrečių žmonių poelgius.

Paskutini dešimtmetị stebimas neabejotinas visuomenès savimonès progresas, kuris apnuogina labiausiai pažeidžiamas vietas teismo psichiatrijos ekspertizès teorijoje ir praktikoje. Taip atsitiko todèl, kad teismo psichiatrija kaip biosocialinis mokslas turi tiesioginę įtaką žmogaus teisėms ir bet koks ekspertinis sprendimas turi poveikị individo socialiniam statusui bei visada sąlygoja tam tikras socialines pasekmes [4]. Taigi, nors dabartinè nepakaltinamumo formulè su pagrindiniais savo elementais teisèkūroje naudo- 
jama jau per 100 metų, iki šiol ji sulaukia daug dèmesio, dažnai yra kritikuojama žiniasklaidos atstovų, politikų, teisininkų, psichiatrų. Be abejo, ekspertai, nuolat ieškantys kompromiso tarp medicininio bei teisinio kriterijaus, dažniausiai susiduria su egzistuojančiu prieštaravimu tarp teorinio požiūrio ir ekspertinès teismo psichiatrijos praktikos. Reikia pripažinti, kad dabartinès nepakaltinamumo formulès konvenciali redakcija pasižymi abstraktumu ir simboliškumu. Ji veikia santykinių susitarimų tarp teisèsaugos struktūrų ir ekspertų psichiatrų pagrindu. Nepakaltinamumo formulès intelektinis požymis apima įstatymu uždraustos veikos ir jos pavojingumo sąvoką, kaip aplinkybę, kurios asmuo negalejo suvokti, tačiau baudžiamojo įstatymo numatytų uždraustų veikų nesupratimą gali sąlygoti ne tik psichikos sutrikimas, o tiesiog paprastas nežinojimas. Teiginys, kad nepakaltinamas asmuo dèl psichikos sutrikimo negali suvokti veikos pavojingumo arba valdyti savo veiksmų, mūsų požiūriu, taip pat yra labai sąlyginis. Net esant ryškiems psichikos sutrikimams (psichozèms) asmenims nèra būdingas totalinis elgesio sutrikimas, daugelis veiksmų gali būti socialiai teisingi, o socialiai pavojingi veiksmai, sąlygoti psichologiškai suprantamų motyvų [6]. Ekspertinejje praktikoje didelę reikšmę ịgauna racionalumo principas, kuris, pavyzdžiui, plačiai naudojamas Danijos ekspertinès teismo psichiatrijos praktikoje. Danijos ekspertai neabsolitizuoja nepakaltinamumo formulès kriteriju ir ekspertinius sprendimus priima atsižvelgdami i tai, kokiomis sąlygomis taikomos medicinos reabilitacinés priemonès bus maksimaliai efektyvios ir trumpesnès, grąžinant nusikaltusị asmenị ị visuomenę [4].

Šizofrenijos spektro sutrikimus turinčių asmenų teismo psichiatrinis įvertinimas baudžiamojoje relevantinèje situacijoje vykdomas plačiu diapazonu. Nuo besąlyginio šios diagnozès tapatinimo su asmens nepakaltinamumu iki diferencinio požiūrio ị atskirų būsenų išskyrimą ir remisijos variantų, kurių metu įmanomas ịvairus sugebejjimo laipsnis suvokti savo veiksmų faktinị pobūdị ir pavojų visuomenei ir vadovauti veiksmais [5].

Darbo tikslas - atlikti pakaltinamų asmenų, turinčiu šizofrenijos spektro sutrikimus, psichopatologiniu mechanizmų, sociopsichologinių, kriminalinių ir situacinių motyvacinių charakteristikų fenomenologinę analizę bei apibréžti riboto pakaltinamumo kriterijų taikymą, šiai asmenų grupei atliekant teismo psichiatrijos ekspertizę.

\section{Darbo objektas ir metodai}

Diagnostinių bei ekspertinių sprendimų analizei panaudoti 2010-2012 m. Valstybinès teismo psichiatrijos tarnybos prie SAM ambulatorinių bei stacionarių teismo psichiatrijos ekspertizių aktai (forma Nr. 192/a) (N=223), kuomet ekspertizès metu asmenims buvo diagnozuoti šizofreninio spektro sutrikimai ir teismui buvo rekomenduota šiuos asmenis pripažinti pakaltinamais. Ši diagnostinè grupè buvo pasirinkta dèl iki šiol dominuojančių pozicijų tarp nepakaltinamų asmenų. Informacijos atranka atlikta pagal specialujji klausimyną, sudarytą šio darbo autorių. Tyrimui panaudotos tik šizofrenijos, šizotipinio ir šizoafektinio sutrikimų diagnostinès grupès, kadangi kiti šio spektro sutrikimai yra pavieniai ir statistiškai nepatikimi. Skaičiavimai atlikti naudojantis SPSS statistiniu duomenų apdorojimo programiniu paketu.

\section{Darbo rezultatai ir jų aptarimas}

2010-2012 metais, atliekant teismo psichiatrijos ekspertizę baudžiamajame procese, buvo diagnozuotas 541 (100\%) šizofrenijos spektro sutrikimas, iš jų $65 \%$ sudare šizofrenija sergantys asmenys, $25 \%$ - šizoafektiniu sutrikimu ir 10\% - šizotipiniu sutrikimu.

Bendroje diagnostinèje šizofrenijos grupejje nepakaltinamais buvo rekomenduota pripažinti $53 \%$, ribotai pakaltinamais $-2 \%$. Pakaltinami tiriamieji sudare $45 \%$, o tai reiškia, kad beveik pusė asmenų, sergančių šizofrenija, šizotipiniu ar šizoafektiniu sutrikimais, buvo patraukti realioje baudžiamojoje atsakomybeje. Palyginimui galima pasakyti, kad sovietmečio laikotarpiu Lietuvoje šizofrenijos diagnostinejje grupeje tik apie $7 \%$ tiriamujų buvo pripažįstami pakaltinamais, o šizofrenijos grupès diagnozavimo dažnumas beveik nepakito [8].

Mūsų analizuojamoje pakaltinamujjų grupejje šizofrenijos diagnozè sudare $48 \%$, šizoafektinio sutrikimo - $41 \%$ ir $11 \%$ šizotipinio sutrikimo diagnozè.

Tyrimo metu atlikta statistinè analizè suteikia galimybę sudaryti šios diagnostinès grupès pakaltinamų asmenų socialinę-demografinę charakteristiką, kuri parodè, kad 89\% šios grupés tiriamujų sudare vyrai ir $11 \%$ - moterys. Didesne tiriamujų dalis buvo aktyvaus 18-40 metų amžiaus vyrai, kurie sudare $62 \%$ (1 pav.).

$76 \%$ tiriamujų turejo vienoki ar kitokị išsilavinimą, tačiau $24 \%$ asmenų nebaigè vidurinès mokyklos (2 pav.).

Beveik puse tiriamujų neturejo jokio darbo $(47 \%)$ ir $43 \%$ darbingumas buvo ženkliai apribotas dèl turimo psichikos sutrikimo. Dauguma asmenų, t. y. 78\%, buvo vieniši, tai yra nevedę arba išsituokę. Gauti tyrimo duomenys leidžia teigti, kad socialinès situacijos nestabilumas, žemas tiriamujų socioekonominis statusas paprastai sąlygoja nepalankią šizofrenijos proceso dinamiką ir nusikalstamą veiką.

Atliekant šizofrenijos grupès pakaltinamų asmenų nusikalstamos veikos analizę, nustatyta, kad beveik po lygiai pasiskirste tiriamujų nusikalstama patirtis: $48 \%$ sudare asmenys nusikaltę pirmą kartą ir $52 \%$ - du ir daugiau kartų. 
Dominuojančią poziciją užima nusikaltimai nuosavybei - $43 \%$ ir visuomenès saugumui, tai dažniausiai neteisètas narkotinių medžiagų laikymas ir realizavimas - 32\%; taip pat reikšmingą dali $-22 \%$ sudarè nusikalstama veika, sąlygota fizinès agresijos; seksualiniai nusikaltimai nèra būdingi šiai diagnostinei grupei, jie sudare tik 3\% (3 pav.).

Dažniausiai nusikaltimai buvo vykdomi vienasmeniškai, t.y. $65 \%$ ir planuotai - 58\%. Impulsyviai padaryti nusikaltimai praktiškai visada buvo susiję su heteroagresija ir homicidais. Atkreiptinas dèmesys ị tai, kad atliekant teismo psichiatrijos ekspertizę, metodiškai svarbu remtis tuo, kad kiekviena situacija kelia savo reikalavimus socialiai priimtinam reagavimui, todèl teismo psichiatrijos praktikoje kiekvienos ekspertų išvados pritaikymas turi būti integralus, atsižvelgiant į nusikalstamą situaciją, BK straipsnị, nusikaltimo grupinị ar negrupinị pobūdị, tiriamojo vaidmenị jame, jo motyvaciją ir kitas aplinkybes. Kiekvienu konkrečiu atveju būtina nustatyti nusikalstamo elgesio rizikos veiksnių prioritetus, kurie buvo igyvendinti nusikalstamame poelgyje.

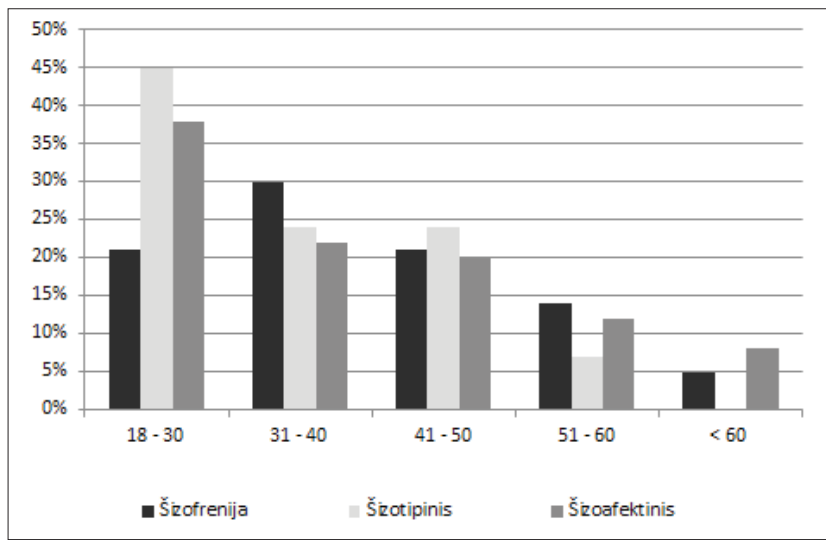

1 pav. F20, F21, F25 pasiskirstymas pagal amžių (2010-2012 m.)

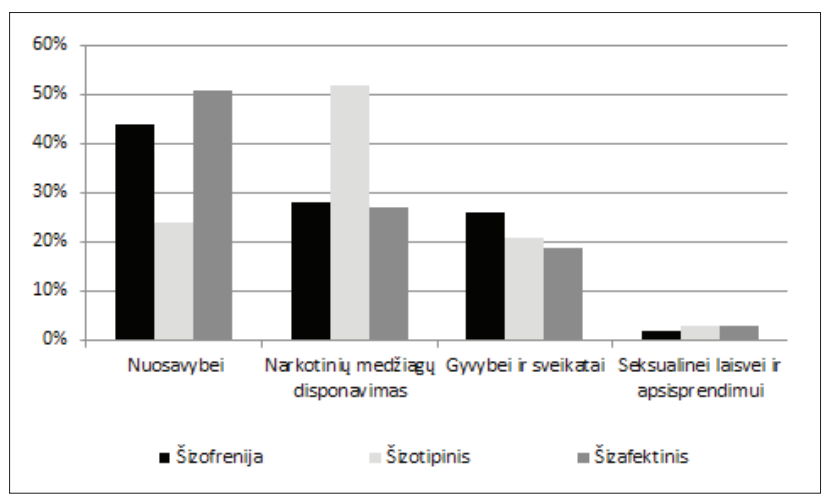

2 pav. F20, F21, F25 pasiskirstymas pagal išsilavinimą (2010$2012 \mathrm{~m}$.)
Vertinant tiriamujų nusikalstamos veikos motyvaciją, nustatyta, kad dauguma tiriamuju - $42 \%$ atkakliai neigè įvykdytą nusikalstamą veiką arba perkeldavo savo kaltę kitiems - 24\%. 13\% tiriamujų padarytų nusikaltimų priežastį apibūdina „buvau girtas“ ir 11\% - ,reikèjo pinigų“. Pažymètina, kad 10\% tiriamujų nusikalstamos veikos motyvaci-

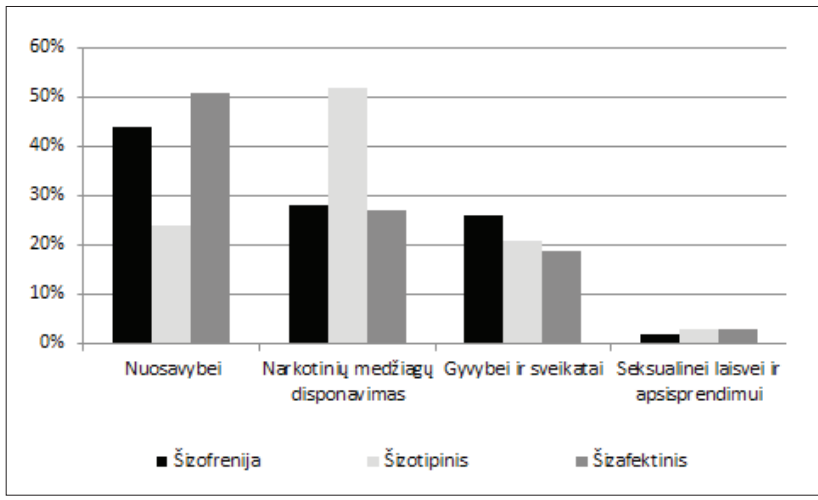

3 pav. F20, F21, F25 pasiskirstymas pagal nusikaltimo pobūdị (2010-2012 m.)

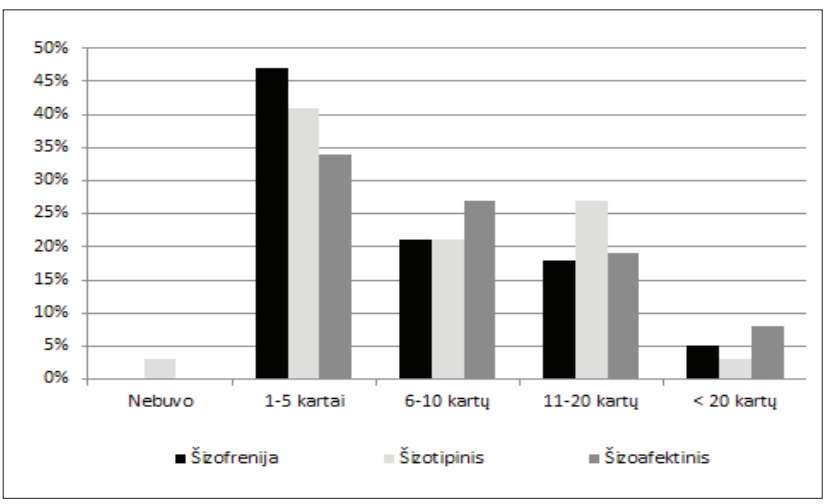

4 pav. F20, F21, F25 hospitalizacijos iki nusikalstamos veikos

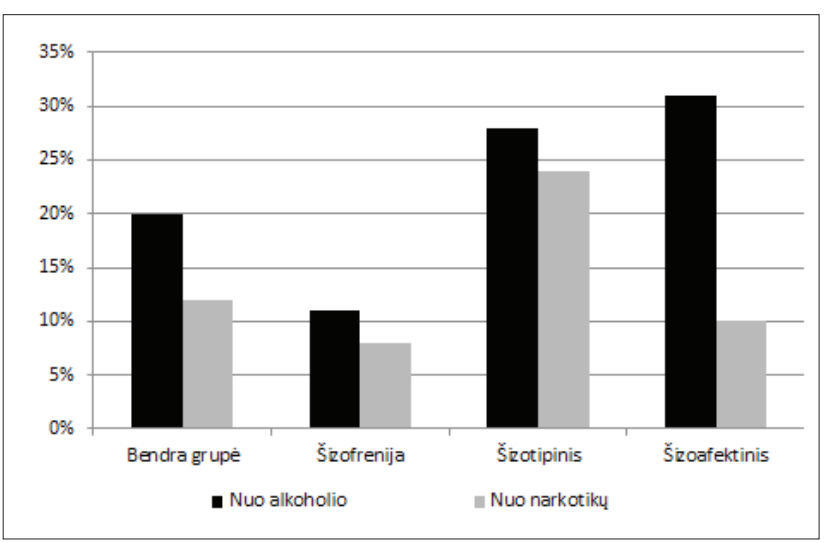

5 pav. Priklausomybès sindromo pasiskirstymas 
ją ekspertai įvertino kaip liguistą, pavyzdžiui: „propagavau lytinị švietimą jaunimui“, „nemėgstu kai vadovauja kiti“, „,norejau parodyti, kad policija blogai dirba“, ,pajutau impulsą padaryti priešiškai“, „mane pakišo vidinis balsas“, „,pamačiau parduotuvejje keptuvę, supratau kad man jos reikia“, „nes kaimyné vilioja vyrą“, „tai atlygis už globą“ ir t.t.

Analizuojant tiriamuju hospitalizacijas i psichiatrijos istaigas, nustatyta, kad iki teismo psichiatrijos ekspertizès atlikimo tik $2 \%$ visų tiriamujų nei karto nesigydè stacionare, tačiau $26 \%$ tiriamujų buvo rehospitalizuojami apie 10 kartų, 20\% - apie 20 kartų ir 6\% tiriamujų gydèsi psichiatrijos ligoninejje daugiau kaip 20 kartų (4 pav.).

Vertinant pakaltinamų asmenų šizofrenijos grupès klinikines charakteristikas, ekspertizès metu 95\% tiriamuju buvo konstatuoti sutrikimai emociniame lygmenyje. Pažymètina, kad emocijų neadekvatumas konstatuotas $12 \%$ asmenų, 67\% tiriamujų nustatytas emocinis šaltumas, skurdumas, blankumas, 31\% tiriamųų konstatuota apatija, $33 \%$ tiriamųjų nustatyta neadekvačiai pakili nuotaika, 27\% sudare tiriamieji, kuriems buvo nustatytas nuotaikos svyravimas nuo pakilios iki prislègtos.

Asmenybės bruožų vertinime $36 \%$ dominavo egocentriškumas, gynybiškumas - 29\%, primityvumas - $27 \%$.

Mąstymo sutrikimai buvo konstatuoti $76 \%$ asmenų, iš jų 56\% sudare nenuoseklus mąstymas, 16\% - sulètintas mąstymas, $22 \%$ - rezonavimas ir 38\% - paraloginis mąstymas.

Dviem tiriamiesiems ekspertizès metu buvo konstatuoti psichozès reiškiniai - kliedejjimo idèjos ir haliucinacijos.

Atkreiptinas dèmesys, kad šioje diagnostinėje grupeje $32 \%$ tiriamujų asmenų buvo diagnozuotas priklausomybès sindromas: $20 \%$-alkoholiui ir $12 \%$ - narkotinèms medžiagoms (5 pav.).

Tokiais atvejais palyginti nesudetinga buitinè situacija dèl apsvaigimo nuo alkoholio ar narkotikų gali būti suvokiama kaip subjektyviai neturinti išeities su socialiai priimtino reagavimo iškraipymu.

\section{Išvados}

1. Heteroagresyvūs veiksmai, esant šizofrenijos spektro sutrikimams, dažnai vyksta ne dèl psichozinių ar subpsichozinių, o dèl realių buitinių motyvų.

2. Kai psichopatologiniai sutrikimai nepakankamai išryškejję, jų ryšys su psichologiniu kriterijumi gali būti ginčytinas, o ekspertų vertinamas būna skirtingas. Tokiais atvejais labai svarbu remtis klinikinio vaizdo dinamika bei socialine adaptacija.

3. Asmenims, turintiems šizofrenijos spektro sutrikimus, esant nepsichozinèms būklèms, juridiniu aspektu ypatingą reikšmę turi psichopatologija, kuri pasireiškia integracinèje visumoje, ir gali ją sustiprinti, o kai kuriais atvejais, priešingai, psichopatologiniai simptomai kompensuoja vienas kitą. Atskirų psichopatologinių fenomenų integracija gali riboti asmens elgesio laisvę konkrečioje situacijoje. Vadinasi, ypatingą vaidmenį ekspertizei turi būtent neryškios patologijos elementų suderinimo analizè.

4. Visuomenei pavojingos veikos, keliančios aukštus reikalavimus afektinès sferos pilnavertiškumui, metu, asmenims, turintiems šizofrenijos spektro sutrikimus, pakaltinamumo kriterijais nelaikomas nepakankamas emocijų diferencijavimas, sintoniškumo sumažejimas, vientisinio emocinio reagavimo susiskaidymas, afektiniai svyravimai, neigiamų emocijų išstūmimo sunkumai, nesugebejjimas jausti aukštas emocijas, afektinis rigidiškumas, tarpusavio santykių niuansų nesupratimas. Išvardintos ypatybės gali reikštis įvairiuose deriniuose, tačiau tai neužtikrina visiško elgesio reguliavimo. Izoliuotai pažymèti sutrikimai nereikšmingi, bet kai jie sustiprina vienas kitą, psichopatologinè būklè gali atitikti riboto pakaltinamumo valios kriterijų. Tokiais atvejais subjektas gali formaliai suvokti savo neteisètų veiksmų esmę, jų socialinị nepriimtinumą, bet vien tik elgesio reguliavimo intelektinis komponentas be emocinio neleidžia daryti išvados apie valios aspekto pilnavertiškumą.

5. Visuomenei pavojingos veikos padarymo metu, kai asmens valios sferai keliami aukšti reikalavimai, riboto pakaltinamumo kriterijais galima laikyti impulsyvumą, hipobulijos simptomus, pasyvaus pavaldumo ir ịteigimo derinị, sugebejjimo tikslingai ir aktyviai veikti praradimą, intelektualinès kontrolès ir iniciatyvos sumažejimą.

6. Esant ribotam sugebejjimui suvokti savo veiksmų faktini pobūdị ir pavojų visuomenei turi būti stebima psichopatologinès būklès stabilizacija su afektinių sutrikimų transformacija ị neryškius, daugiausia asteninius subdepresinius sutrikimus.

7. Šizofrenijos spektro sutrikimų atvejais, esant kai kuriems nusikalstamos situacijos variantams, žalingi veiksniai gali lemti ribotą pakaltinamumą ir net nepakaltinamumą, kai asmenybės pakitimai yra nereikšmingi.

\section{Literatūra}

1. Abramavičius A., Čepas A., Drakšienė A. Nocius J., Pavilonis V. ir kt. Baudžiamoji teisè. Vilnius, 2003; 188-191.

2. Justickis V. Bendroji ir teisès psichologija. Vilnius, 2003.

3. Dmitrijeva T., Šostakovič B., Tkačenko A. Teismo psichiatrijos vadovas. Maskva, 2004; 75.

4. Gunn J, Taylor PJ. Forensic psichiatry: clinical, legal and ethical issues. GB, 2000.

5. Tkačenko A. Teismo psichiatrijos vadovas. Maskva, 2012; 209-241. 
6. Pervomajskij V. Nepakaltinamumas. Kijevas, 2000; 85-111.

7. Gierowski J. K., Godlewski J., Heitzman J., Jędrzejowska R., Kołakowski S. Postępowanie karne I cywilne, wobec osób zaburzonych psychicnie. Kraków, 1996; 85, 131.

8. Daškevičius K. Nepakaltinamumo formulès raida Lietuvoje, Vilnius, 2006.

\section{THE ANALYSIS OF THE APPLICATION OF DIMIN- ISHED RESPONSIBILITY CRITERIA FOR PERSONS WITH SCHIZOPHRENIA SPECTRUM DISORDERS}

\section{K. Daškevičius, J. Daškevičienė}

Key words: forensic psychiatry evaluation in criminal cases, diminished responsibility.

\section{Summary}

In improving the modern law, increasing its humanistic potential, overcoming the traditional formalistic-bureaucratic nature of law, its apathy, reducing the psychologically traumatising effect for persons with psychological disorders, the diminished responsibility norm was put into force in 2000. However, it is seldom realised in the Lithuanian forensic psychiatry evaluation practice, while it is applied to persons with schizophrenia spectrum disorders even more seldom - only in 10 cases out of 541 in 3 years. According to the data of our study, as many as $84 \%$ of $223(100 \%)$ responsible persons with schizophrenia spectrum disorders meet the diminished responsibility criteria. However, the multiannual systemic evaluation of psychological state of the person under the investigation is not referred to when carrying out the forensic psychiatric evaluation on persons with schizophrenia spectrum disorders and instead clinical biological, psychological personality, and medical social evaluation is referred to, while the most prominence is given to retrospective determination of psyche disorder depth at the moment of the criminal offence. The data of the study shows that from the legal aspect the psychopathology, which manifests in the inclusive whole and can consolidate it, is especially significant to persons with schizophrenia spectrum disorders in non-psychotic states. This in turn means that the integration of separate psychopathologic phenomena may limit a person's behavioural freedom in a specific situation. Hence, the harmonisation analysis of indistinct pathology elements plays an important role in the evaluation.

Correspondence to: info@ntpt.1t

Gauta 2015-12-14 